\title{
Correction to: Physico-chemical, Sensory and Toxicity Characteristics of Dipeptidyl Peptidase-IV Inhibitory Peptides from Rice Bran-derived Globulin Using Computational Approaches
}

\section{Km Pooja ${ }^{1}$ - Sapna Rani ${ }^{2}$}

Published online: 5 December 2017

๑) Springer Science+Business Media, LLC, part of Springer Nature 2017

\section{Correction to: Int J Pept Res Ther \\ https://doi.org/10.1007/s10989-017-9586-4}

The original version of this article unfortunately contained an error.
The authors agree to withdraw the authorship of Balaji Kanwate and Gaurav Kumar Pal from the article as both of the authors have not sufficiently contributed to this manuscript. The correct author group is Km Pooja ${ }^{1}$, Sapna Rani ${ }^{2}$.

The online version of the original article can be found under https://doi.org/10.1007/s10989-017-9586-4.

Km Pooja

poojapal10593@gmail.com

$\triangle$ Sapna Rani

sapnarani200492@gmail.com

1 Department of Botany, Chaudhary Charan Singh University, Meerut, Uttar Pradesh 200005, India

2 Dairy Microbiology Division, ICAR-National Dairy Research Institute, Karnal, Haryana 132001, India 